\title{
Preserving Workers' Dignity in Workers' Compensation Systems: An International Perspective
}

\author{
Katherine Lippel, LLL, LLM*
}

\begin{abstract}
Background Workers' compensation systems are among the most generous disability insurance systems in North America, although they are also known to be potentially adversarial and may have iatrogenic effects on claimants. This article examines issues to be considered to ensure fair compensation provided in a way that respects the dignity of workers.

Methods An overview of the literature on characteristics and effects of workers' compensation systems is followed by an analysis based on classic legal methods, including those of comparative law, complemented with interview data to examine three models of disability compensation.

Results The first part of the article identifies cross cutting issues to be considered in the examination of the equity of compensation systems and the protection of the dignity of claimants. These include three underpinnings of workers' compensation: the links between a "no-fault" system and the adversarial process, the appropriate use of medical and scientific evidence in the determination of compensability and the application of appropriate measures for promoting return to work. The second part looks at accident compensation in New Zealand, where compensation is available regardless of the cause of the accident, and disability insurance in the Netherlands, where compensation is available regardless of the cause of the disability. It then describes a composite of characteristics favorable to equity drawn from the thirteen workers' compensation systems in Canada.

Conclusion Systems that succeed in reducing opportunities for adversarial interactions and that provide substantive protection could better promote the dignity of claimants. Am. J. Ind. Med. () 2012 Wiley Periodicals, Inc.
\end{abstract}

KEY WORDS: workers' compensation; Canada; New Zealand; Netherlands; iatrogenic effects; stigma; medico-legal issues; scientific uncertainty; return to work; adversarial systems

Canada Research Chair in Occupational Health and Safety Law, University of Ottawa, Faculty of Law (Civil Law Section), Ottawa, Ontario, Canada

Contract grant sponsor: Social Science and Humanities Research Council of Canada.

Conflicts of interest: A preliminary version of this paper was prepared for a meeting organized by the National Economic \& Social Rights Initiative (NESRI) and entitled Rethinking Workers' Compensation: Developing Strategies to Protect Injured/III Workers' Basic Human Rights and the author acknowledges having received remuneration for the preparation of that paper. The author has no conflict of interest to declare.

${ }^{*}$ Correspondence to: Prof. Katherine Lippel, LLL, LLM, 603 King Edward ave., Ottawwa, Ontario, Canada K1N6N5.E-mail: klippel@uottawa.ca

Accepted 23 January 2012

D0I 10.1002/ajim.22022. Published online in Wiley Online Library

(wileyonlinelibrary.com).

\section{INTRODUCTION}

This article looks at key issues that should be addressed in an injury/disability compensation system designed to meet the needs of those who are injured while respecting their right to be treated with dignity. It examines literature on workers' compensation schemes and their effects on claimants' health, dignity and well being and draws on examples, from the standpoint of workers [Eakin, 2010], of good and bad practices from a variety of workers' compensation systems outside of the United 
States. Examples are primarily drawn from the Canadian experience, but illustrations from Australia [Safework Australia, 2011] and Europe are also included.

The article is structured in two parts. The first provides an overview of issues described in the literature as being a source of positive or negative outcomes for workers in compensation systems, looking, on the one hand, at the importance of the social safety net provided by workers' compensation systems and, on the other hand at three dominant discourses in the discussion of workers' compensation: the non-adversarial nature of no-fault compensation systems, the evidence-based decision making process and the promotion of return-to-work incentives. The article identifies four cross cutting issues that need to be considered in the examination of the equity of compensation systems. These include (1) non-adversarial access to adequate benefits and health care (2) in a way that ensures the protection of the dignity of claimants by preventing stigma and ensuring balance, (3) appropriate use of scientific evidence in the determination of compensability, and (4) the application of appropriate measures for promoting return to work. The second part focuses on key components of compensation schemes in New Zealand and the Netherlands, considering whether or not those schemes meet these objectives. The New Zealand system is of interest as it is the first "no fault" system to be extended to all disability related to an accident, regardless of the cause of the accident. The system replaces tort law, preventing lawsuits for injury or illness falling within the purview of the legislation and is, in this regard, similar to most workers' compensation schemes. The disability insurance system in the Netherlands was chosen because it was the first system to provide disability benefits linked to pre-injury earnings regardless of the cause of the disability, replacing workers' compensation and other programs by a universal system in 1967 [Wilthagen, 2002]. Unlike the New Zealand scheme and most workers' compensation schemes, the Dutch disability insurance system does not affect claimants' right to sue those responsible for their injury. In recent years all systems have placed more emphasis on return to work, and this will be included in the overview. Finally, a composite model of systems in force in Canada provides other suggestions as to ways forward. No system currently includes all these parameters, however a composite overview allows for a better conceptualization of potential reforms.

The article concludes with a reminder that the International Labor Organization has provided parameters by which protections to injured workers are guaranteed and that many European countries provide much broader social security protections that make workers' compensation less crucial to workers because a social safety net exists regardless of the cause of the injury. It suggests that regardless of the rules of the compensation system, the philosophy of the institution responsible for its implementation must, itself, be predicated on respect for claimant dignity, fairness and justice, and on the avoidance of stigmatization, if a system is going to better serve those who are injured or made ill because of their work.

\section{METHODS}

Material in this article was gathered through a variety of methods. It primarily relies on classic legal and policy analysis of workers' compensation and disability insurance schemes in several jurisdictions. Research on the Canadian compensation systems examined sources relevant to the systems in force in major provincial jurisdictions, and included the study of legal and policy literature, legislation and administrative tribunal decisions in English and French.

Information regarding the disability insurance systems in force in New Zealand and the Netherlands was obtained through analysis of the English language sources available in the legal and policy literature. This was then completed by interview data concerning compensation systems in those countries. Interviews with key informants from the New Zealand Accident Compensation Commission (ACC), associations representing claimants, employers and unions took place during three site visits held in 1989, 2003, and 2006.

Information on the disability insurance system in the Netherlands was obtained through interviews with a variety of stakeholders, including spokespersons for the WAO (the organization that was then mandated to implement the scheme), associations representing claimants, and unions. These interviews were held during two site visits in 2003 and 2005. Updated information was obtained through exchanges and discussions with key informants familiar with the Dutch system.

With regard to the interview data, verbal consent was obtained from the participants, and some of the interviews were audio-recorded; no formal IRB approval was obtained given that the subjects were policy specialists and the interviews were about technical aspects of policy application and not about the subjects' personal feelings about those policies. Policy materials provided by informants were analyzed, as well as new materials now publicly available through the Internet, including recent annual reports of the institution.

\section{WORKERS' COMPENSATION SYSTEMS: POSITIVE AND NEGATIVE ATTRIBUTES}

\section{Does Workers' Compensation Ensure Adequate Benefits and Healthcare?}

Workers' compensation systems have existed in North America, Europe, and Australia since the late nineteenth 
and early 20th century, long before the introduction of social security and health insurance [Lippel, 1981-1982; Himmelstein et al., 1999; Fishback and Kantor, 2000]. They were, and still are in many countries, the disability insurance system that provides the highest level of benefits [Organisation for Economic Co-operation and Development, 2010] and the best access to healthcare services [Hurley et al., 2008]. Since the early 1970s, all residents of Canada have access to free medical services regardless of the cause of their injury [Hurley et al., 2008], so the medical insurance provided by workers' compensation while useful, is not essential to Canadian workers in the same way as it has been in the United States [Herbert et al., 1999; Hamm et al., 2007]. Australian studies have also found that public healthcare benefits pick up the costs of care for many work related injuries and disease [Quinlan and Mayhew, 1999].

Most workers' compensation systems in North America and Australia tie the level of benefits to pre-injury earnings, a characteristic of key importance for people suffering from work disability as they therefore provide benefits that are higher than those provided by the other public disability insurance systems [Mustard et al., 2008].

Although a few jurisdictions in both Australia and Canada offer public no-fault motor vehicle accident compensation schemes [Sugarman, 1998], for most people, when work is not the demonstrated cause of injury, public disability insurance systems are the only broadly available economic support systems and they provide a far lower level of benefits. This is certainly true in Canada, where maximum benefits paid under the Canada Pension Plan are below the poverty line, and access to these benefits is difficult [Organisation for Economic Co-operation and Development, 2003, 2010].

Aside from this limited disability insurance, available only to those who have contributed sufficient premiums, in Canada, as in Australia, the only other sources of public economic support are means tested, forcing the worker to exhaust all resources before providing subsistence level benefits if the family unit is destitute. Levels of benefits for workers who are injured at work are far better than those that would otherwise be available, and physical, social, and vocational rehabilitation programs are far superior for those injured at work than for other people suffering from work disability, unless they have access to some form of private insurance [Bernhard et al., 2010; Organisation for Economic Co-operation and Development, 2007, 2010].

Mutualized private or employer provided insurance is mandatory in most European jurisdictions [Organisation for Economic Co-operation and Development, 2003; Anema et al., 2009], but this is not the case in Canada and close to half of the Canadian working population have no access to such benefits [Organisation for Economic
Co-operation and Development, 2010]; those who are precariously employed, rarely have access to salary replacement benefits in the case of injury or disease that leads to work disability [Quinlan and Mayhew, 1999; Marshall, 2003], unless the cause of the ensuing disability is work.

While the systems have survived for more than a century and provided a substantive safety net for injured workers, some studies have pointed at the overly limited scope and quality of support provided and certain characteristics of implementation processes have been identified as potential sources of negative consequences for claimants.

\section{Discourses Underpinning Workers' Compensation Systems}

Workers' compensation systems, at their best, provide a safety net for those injured at work, but several studies have found that net to sometimes have holes that contribute to system failure. Examination of three elements of the dominant discourse underpinning workers' compensation provides an opportunity to shed light on the system from the workers' perspective: workers' compensation as a non-adversarial system; evidence-based decision making and incentives for return to work.

\section{Is Workers' Compensation a Non- Adversarial System?}

\section{Does no-fault mean no blame?}

From the early twentieth century workers' compensation systems were designed to replace tort action against the employer, to provide benefits to workers regardless of their fault or that of their employer, and to this day, all workers' compensation systems in Canada, and some systems in Australia, prohibit tort based law suits against employers for work-related injury in exchange for the right to "no-fault" compensation. The degree of protection from law suits that is accorded to employers varies, but in its broadest application, in some Canadian provinces, employers may not even be sued for sexual harassment or bullying, or any other human rights violation, if the plaintiff seeks damages for physical or mental health problems attributable to these human rights violations [Lippel, 2011]. While the replacement of tort based claims by "no-fault" compensation is a positive step, eliminating what Ison accurately described as the forensic lottery [Ison, 1968], the elimination of tort does not imply that workers' compensation is a non-adversarial system as the adversarial nature of a process does not necessarily imply that the claim has been the object of litigation [Strunin and Boden, 2004]. Nor does the elimination of tort preclude attribution of blame, particularly with regard to the 
victim [Lippel, 1999]. The invitation addressed to employers on claim forms to contest claims, or the availability of "snitch lines" on workers' compensation board websites are just two illustrations of ways in which systems encourage an adversarial process, long before a claim is denied or an appeal is filed [Eakin et al., 2009]. As we shall see, disability and absence management systems may also be perceived as confrontational in Canada [MacEachen et al., 2010], Great Britain [Coole et al., 2010], and Australia [Roberts-Yates, 2006].

Workers' experience of workers' compensation systems vary considerably, depending on many variables [Grant and Studdert, 2009]. Those with visible, physical injuries that occur as a result of acute trauma are less likely to have a confrontational relationship with a compensation system than those who suffer from soft tissue injury, neurological damage, mental health problems, or from controversial illnesses [Lippel, 2008]. Those suffering from fibromyalgia [Fabris, 2004; Le Page et al., 2008], multiple chemical sensitivities [Astroff, 1998; Phillips, 2010], and musculo-skeletal disorders [Reid et al., 1991; Lippel, 2003a; Morse et al., 2003] are often subjected to a highly adversarial process which encourages underreporting.

Those suffering from occupational diseases, even notorious occupational diseases like lung cancer and asbestosis, will have a more difficult experience with the compensation system than those suffering from a traumatic injury, regardless of whether litigation is required [Leigh et al., 1999]. Under-reporting of occupational disease is known to be high in many jurisdictions [Shannon and Lowe, 2002; Biddle and Roberts, 2003; Morse et al., 2004; Réseau 'Surveiller les Cancers d'Origine Professionnelle en Seine Saint-Denis' (GISCOP93), 2005], although a significant number of acute injuries have also been shown to go underreported in Canada [Shannon and Lowe, 2002; Vézina et al., 2011] and the United States [Azaroff et al., 2002]. In highly adversarial systems even those suffering from acute trauma as a result of obvious industrial accidents may well be submitted to abusive contestation and suggestions of "moral hazard," strategies that contribute to underreporting [Boden et al., 2001]. Recent U.S. estimates indicate that the "proportion of self-reported work-injured persons for whom medical treatment was paid by workers' compensation insurance ranges from $47 \%$ in Texas to $77 \%$ in Kentucky" [Centers for Disease Control and Prevention (CDC), 2010].

Women [Chung et al., 2000; Lippel, 2003a], members of racialized or linguistic minorities [Herbert et al., 1999; Premji et al., 2008a] and immigrant workers [Azaroff et al., 2004; Gravel et al., 2010; Guthrie and Quinlan, 2005] have been shown to have more difficulties in accessing compensation. Studies in Canada [Ison, 1986; Lippel, 1999; Beardwood et al., 2005; Eakin, 2005; Lippel, 2007;
MacEachen et al., 2007a, 2010], Australia [Roberts-Yates, 2003; Sager and James, 2005], and the United States [Lax and Manetti, 2001; Strunin and Boden, 2004] have shown that many workers' compensation claimants report feeling stigmatized by the process, blamed for being an injured worker, and shunned by the community and healthcare professionals because of their status as an injured worker.

A second, and related issue is the imbalance in power between workers, the compensation system and employers [Beardwood et al., 2005]. The adversarial nature of the process exacerbates this imbalance, and when litigation is frequent, adverse health consequences may be more prevalent.

The adversarial nature of a system is thought to increase in systems that are highly experience rated [Ison, 1998; Pransky et al., 1999; Lippel, 2007; Quinlan et al., 2010]. Although appeals are only a small part of the adversarial process, an increase in appeals over the years can provide an indicator of the increasing adversarial nature of the system.

Focus on a Québec example illustrates the mechanisms by which experience rating contributes to the adversarial nature of the compensation process. Although accident prevention legislation in Québec has been in force since the nineteenth century, the Québec occupational health and safety system was ranked among the worst in North America [Block and Roberts, 2000]; occupational health and safety committees are not mandatory in the vast majority of workplaces, and fines are remarkably low. The same institution is responsible both for workers' compensation and occupational health and safety; experience rating, rather than rigorous occupational health and safety regulation is the primary deterrence strategy. A variety of system actors interviewed [Lippel, 2007] have noted an increase in contestation of claims since the 1990s, when emphasis on experience rating was accentuated. In an early study measuring the effect of increased experience rating in Québec [Thomason and Pozzebon, 2002] it was found to be associated with aggressive claims management practices, as well as prevention practices. While some workers have described the actual appeal hearing as having therapeutic effects, practices associated with the appeals process are often prejudicial to workers' health. For example, clandestinely obtained videotape evidence of injured workers' activities is regularly admitted into evidence or used to encourage workers to withdraw their claims [Lippel, 2003b]. More than half the appeals are settled through the conciliation system [Aubé, 2008], and often workers withdraw their claims in exchange for monetary compensation paid unofficially by employers who save money by avoiding experience rated benefits and health care. Studies looking at mediation processes in Québec workplaces suggest, by analogy, that contestation by employers may be driven by the opportunity to strike a 
TABLE I. Claims, Accepted Claims, and Appeals (Québec, 1999-2009)

\begin{tabular}{lccc} 
Year & Claims (CSST) & Accepted claims (CSST)/\%accepted & Appeals (CLP)/\% claims \\
\hline $1999-2000$ & 164890 & $143517(87 \%)$ & $20922(13 \%)$ \\
$2004-2005$ & 152799 & $132906(87 \%)$ & $27141(18 \%)$ \\
$2009-2010$ & 115720 & $95597(83 \%)$ & $32393(28 \%)$ \\
\hline
\end{tabular}

Sources: [Commission de la Santé et de la Sécurité du Travail, 2000, 2005, 2010; Commission des Lésions Professionnelles, 2000, 2005, 2010].

deal in the conciliation process [Poitras et al., 2005]. While alternative dispute resolution mechanisms were designed to avoid trials involving injured workers some studies have found they can also exacerbate the imbalance between workers and the compensation system in Australia [Guthrie, 2002a] or worker and employer litigants in Canada [Aubé, 2009].

Independent appeal tribunals have existed in Québec since 1975, and while the number of occupational injuries compensated has been going down significantly over the past 10 years, the number of appeals has increased substantially, as can be seen in Table I.

The adversarial nature of the Québec system triggers behaviors, like employer mistrust and recourse to private detectives, that stigmatize workers. Other Canadian workers' compensation systems have fewer appeals than in the Québec scheme, as can be seen in Table II.

The lower proportion of initial claims that go to the final appeal tribunal in those provinces may be attributable to a variety of reasons including less sensitive experience rating mechanisms, less recourse to alternative dispute resolution mechanisms at the appeal level, better access to worker representation through the Office of the worker advisor and access to a Fair Practices Commission [Fair Practices Commission of Ontario, 2009]. However, the disparity may be partially explained by the fact that tribunals in Ontario and British Columbia have less latitude and independence than the Québec appeal tribunal because those in British Columbia and Ontario are essentially bound by compensation board policy and not just legislation. In those provinces, the inability to question decisions

TABLE II. Appeals to Final Appeal Tribunal as Compared to Number of Initial Claims (British Columbia and Ontario, 2000-2009)

\begin{tabular}{lcc} 
Year & British Columbia appeals/\% claims & Ontario \\
\hline 2000 & $4757 / 184131(2.6 \%)$ & $6178 / 379097(2 \%)$ \\
$2004 / 2005$ & $5880 / 164443(3.6 \%)$ & $4490 / 352996(1 \%)$ \\
2009 & $4767 / 141968(3.4 \%)$ & $3900 / 249477(2 \%)$ \\
\hline
\end{tabular}

Sources: [Workers' Compensation Appeal Division Annual Report, 2000; Workers' Safety and Insurance Appeal Tribunal Annual Reports, 2000, 2004, 2009; Worksafe B.C. Annual Report, 2005, 2009; Workers' Compensation Appeal Tribunal of British Columbia Annual Reports, 2005, 2010; Workers Safety and Insurance Board, 2010]. based on policy of the Board, could well contribute to the exacerbation of the feeling of imbalance. Despite the lower level of appeals, at least in Ontario, experiences of those with complex claims confirm that contestation of claims even at the initial adjudication level contributes to negative consequences for workers' health and employment prospects [MacEachen et al., 2010].

\section{Does workers' compensation protect claimants' dignity by preventing stigma and ensuring balance?}

Studies have identified specific aspects of compensation systems that contribute to adverse health effects, and addressing these systemic issues would be a first step in reform. Mechanisms by which the adverse effects target workers are often imbedded in seemingly neutral legislative provisions, so it is important to examine both the immediate causes of negative experiences, and the technical provisions of legislation that facilitate or undermine smooth access to the compensation system.

A Québec study [Lippel, 2007] identified three primary issues that explained many of the negative health consequences reported by the workers: stigma, imbalance of power and lack of social support. Workers, including some workers whose claims had been accepted without contestation, reported being "treated like a criminal" or feeling like David confronting Goliath. They expressed with 93 different terms the negative emotions associated with the process; positive experiences were expressed in 23 terms, including feeling "lucky" to have been supported by their union or "proud" to have made it through the process. Those who had social support were more likely to get through the process unscathed, while those who were isolated often reported negative health effects, affecting both their physical and mental health. Sources of social support were varied, and included family members, the treating physician and the worker's union or lawyer, but also the presiding judge in the appeal hearing and occasionally, but less often, the workers' compensation adjudicator. Although every actor in the system was a potential source of stigma, those mentioned most often were physicians working for the employer or the compensation system, employer lawyers at appeal hearings, and, in some 
cases, adjudicators working for the workers' compensation board. Perhaps the most damaging of all was the use, and the specter, of private detectives hired by employers and the Compensation Board to spy on the workers, clandestinely filming those who were perceived to be making movements that were contraindicated by their medical condition [Lippel, 2003b]. This practice contributed both to the stigmatization of workers, and to the feeling of helplessness described by those with the most severe adverse health consequences. Workers' advocates mentioned that suicide prevention strategies were part of their job.

Studies in other Canadian provinces have also identified stigma as a significant issue for injured workers. In Ontario [Eakin and MacEachen, 2003], having a work accident was shown to undermine relationships between employers and workers in small businesses, often because employers in that system felt they were required to police the legitimacy of the worker's claim. This led to distrust between workers and employers, and a new feeling of disrespect for the workers who claimed compensation. The specific role conflicts governing the behavior of front line adjudicators of compensation boards may also contribute to the perception of the system as adversarial, and the stigmatization of claimants [Eakin et al., 2009]. Some workers' compensation boards have explicitly acknowledged the need to reduce stigma towards injured workers and have proactively sought to promote workers' dignity in the compensation process [Eakin, 2010].

Stigma associated with workers' compensation does not necessarily stem from the system itself. Widely held beliefs about injured workers or compensation contribute to the process of stigmatization. Among the vehicles for these beliefs is the concept of moral hazard [Boden et al., 2001].

The scientific community sometimes contributes to stigma, acting as a proponent of the discourse of moral hazard. For example, epidemiologists sometimes include the "compensation issue" as a variable in predicting duration of disability, and sometimes conclude that those subjects who are involved in the compensation process will take longer to heal than the other subjects, an approach that is the subject of scrutiny and that can be problematic [Grant and Studdert, 2009; Spearing and Connelly, 2011]. Studies may confuse receiving benefits with being a claimant, or equate having contacted a lawyer with being in the compensation system; they do not necessarily distinguish between the tort system and workers' compensation and are then cited to show that workers' compensation increases duration of disability. Those studies that measure "compensation" by having contacted a lawyer usually do not discuss why a subject would need a lawyer, and may use benefit duration to measure disability. From a legal perspective, there can be many explanations as to why benefits are paid for a longer period to claimants who have access to lawyers, yet some of these studies conclude that it is the fact that compensation is provided that prolongs disability. Some of these studies may be used to suggest that compensation itself is bad for the worker's health, yet they have no information on the process to which workers are subjected in an adversarial context [MacEachen et al., 2010]. This approach is built on the premise of "moral hazard" [Dembe and Boden, 2000; Campolieti, 2002], that access to benefits will prolong duration of disability, implicitly, or explicitly suggesting malingering, and as such contributes to the stigmatization of workers' compensation claimants. Recent research warns against the use of such studies in the redesign of compensation systems [Spearing and Connelly, 2011].

\section{Evidence-Based Decision Making: Is Science Used Appropriately in Workers' Compensation Systems}

\section{Practice of evidence-based occupational medicine}

Doctors play a gatekeeper role in most workers' compensation and disability insurance systems, although which doctors have a voice in the compensation process varies considerably from one jurisdiction to the next. In some jurisdictions, like in Québec, the opinion of the treating physician, chosen by the worker, is initially binding on the compensation board, while in others, the treating physician's opinion may be set aside more easily, sometimes by decision makers relying on tables governing average healing times or on the opinion of doctors paid by the insurer. Some European jurisdictions do not require medical documentation in the early weeks of work absence [Anema et al., 2009], while other jurisdictions rely on doctors to police workers attempting to access the compensation system, and training of "independent medical evaluators" may be designed to instill wariness and distrust of patients [Lacerte et al., 2004]. In recent years there has been an increasing emphasis on evidence-based practice in occupational medicine in many jurisdictions [McGuirk and Bogduk, 2007; Kok et al., 2008].

Access to health care for injured workers is sometimes difficult because physicians are loath to deal with the system [Lax and Manetti, 2001; MacEachen et al., 2007b; Kosny et al., 2011] and because other physicians, working for employers or the insurance companies, may behave in a way that discourages treating physicians from participating in the process [LaDou, 2006; Philips, 2010a]. Physicians' roles affect access to coverage, determination of benefits, and the return to work process.

Access to benefits often depends on the determination of medico-legal issues that require scientific evidence. Toxic tort and workers' compensation are key fora for the 
exploitation of scientific uncertainty, and co-opting of physicians [Bohme and Egilman, 2008; Guidotti, 2008] and science by industry, and to some extent by governments has been well documented in the contexts of both the regulatory and liability agendas [Michaels, 2008].

Yet scientists have also been at the forefront in the identification of occupational diseases and prevention strategies and can be a significant force in the protection of workers' health. Epidemiology, ergonomics, occupational medicine, and rehabilitation medicine are among several scientific disciplines that feed policy makers concerned with workers' compensation systems. In France, a multi-disciplinary team led by sociologists specialized in occupational health have been documenting work exposures in a population of hospitalized cancer patients, providing new knowledge on occupational cancers and exposure to carcinogens while supporting workers and their families in their claims for workers' compensation [Réseau 'Surveiller les Cancers d'Origine Professionnelle en Seine Saint-Denis' (GISCOP93), 2005].

In Canada, many compensation boards provide financing for scientific research, and while there are some safeguards to ensure that researchers remain independent, the choice of subjects that are funded is influenced by the priorities of the compensation boards, a practice which has, in the past, led to a dearth of research on hazards associated with women's work [Messing, 2002]. In other countries, state funded scientific studies based on statistical analyses of claims data have been used by politicians to justify significant reforms and cutbacks in disability insurance programs [van Oorschot and Boos, 2000].

\section{Use of scientific data in adjudication of occupational disease claims}

Workers' compensation covers occupational disease in all Canadian provinces. As in many jurisdictions, legislation includes a list of occupational diseases presumed to be caused by the corresponding work exposures, and disease claims that do not meet those specifications are nonetheless compensable if it is shown that work was a significant contributing factor in the development of the disease. Yet the vast majority of compensated claims are for accidents, and the success rates for disease claims are lower than those for accidents. In Canada, as elsewhere, scientific uncertainty plays a key role in denial of occupational disease claims [Lippel, 1992; Leigh et al., 1999; Lippel et al., 1999; Ison, 2008].

A recent study of workers' compensation claims for occupational diseases related to asbestos exposure in Canada provides illustrations of ways in which scientific uncertainty serves to diminish workers' chances of receiving compensation [Lippel, 2010a]. The comparison of five Canadian jurisdictions showed that legislative presumptions regarding asbestos related disease varied significantly from one province to the next, in terms of requirements regarding years of exposure, latency periods, and diagnoses presumed to be compensable diseases. While in all provinces compensation was theoretically available, in individual cases, if it was more likely than not that work had contributed to the disease (legal requirement of preponderance of evidence), provincial systems required a far higher degree of scientific certainty when deciding which diseases and which exposures should be scheduled as presumed to be work related. This is only one illustration of ways in which levels of scientific certainty are indirectly imported in an adjudication process that is supposedly based on the preponderance of evidence [Jasanoff, 1995; Cranor, 2006; Premji et al., 2008b]. Over and above the legislative disparities, there were also important disparities between provinces with regard to access to physicians capable of making an adequate diagnosis. Without access to these healthcare professionals, the legal framework that was theoretically more favorable to workers had no effect on the number of workers actually accessing compensation.

In the same study, analysis of administrative tribunal decisions provided evidence that the Chrysotile Institute's discourse regarding Chrysotile asbestos is being used by employer counsel in attempts (thus far unsuccessful) to persuade adjudicators and appeal tribunals to deny compensation for lung cancer and mesothelioma if the evidence shows that workers were "only" exposed to Chrysotile asbestos.

Systems can protect workers from the effect of power imbalance. Québec, the province that still mines asbestos, has a specific adjudicative process reserved for claims for pulmonary disease, a process that involves evaluations of each claim by six different specialists paid for by the compensation board, and trained specifically with regard to evaluation of lung disease. This evaluation process makes it almost impossible for a worker to prevail if the six specialists conclude that he is not suffering from an occupational disease. However, in practice, the opinions of these pulmonary committees supporting compensation, which they often do, will not be easily set aside by opposing views of specialists paid for by the asbestos industry. If independence from industry of these specialists is assured, this model of evaluation may protect a large number of workers who would otherwise be unable to pay for the necessary medical evaluations that would persuade an adjudicator who receives numerous expert opinions from specialists paid for by industry.

Co-opting of science and occupational physicians is a one-sided game in the context of workers' compensation, the workers, even those who are unionized, can not afford a multiplicity of expert opinions to confront the opinion of experts working for their employer or directly for the compensation board. In Canada workers rarely engage an 
attorney on a percentage basis. Assuring and financing access to more independent evaluations, or to medical clinics specialized in occupational disease, is a way to ensure a fairer system. As we shall see in the second part of this article, access to worker representation and specialized clinics is available in some Canadian provinces.

\section{Do Systems Apply Appropriate Measures for Promoting Return to Work?}

Protecting workers' jobs and providing them with support to ensure successful return to work is an important objective of many workers' compensation and disability insurance systems in Europe, North America and Australia [Guthrie, 2002b; MacEachen et al., 2006; Anema et al., 2009]. To be successful, programs require "goodwill and trust" [MacEachen et al., 2006]. Yet disability management systems sometimes are seen to provide incentives to workers to not declare injuries for fear of being perceived negatively by employers [Coole et al., 2010] and not all such systems, be they run by employers or the workers' compensation administrator, are conducive to promoting trust [Soklaridis et al., 2010]. Workers' experience during the return to work process, including the assignment of modified work in the context of early return to work programs, has also been identified as a potential source of humiliation and social exclusion in the U.S., Canada, and Australia [Strunin and Boden, 2000; Eakin and MacEachen, 2003; Sager and James, 2005; MacEachen et al., 2007b; Lippel, 2010b].

The return-to-work process may also be a source of conflict between workers and employers, perhaps more so when the compensation system mandates an early returnto-work process that gets workers back to work before their injury has healed [MacEachen et al., 2007a; Soklaridis et al., 2010]. In the last decade there has been increasing emphasis on the importance of early intervention to reduce work disability, largely driven by the first studies by Waddell on work disability and low back pain [Waddell et al., 2002]. As MacEachen and colleagues have shown, these studies have underpinned a broad range of policy interventions that incite workers to participate in early return to work programs regardless of the nature of their injuries and sometimes regardless of the appropriateness of the proposed return to work program. They promote emphasis on workers' residual abilities, yet policies are conducive to ignoring the impact of pain on the ability to work, a problem not only for workers but for the rehabilitation providers who are called upon to provide them with support [MacEachen et al., 2011]. Perceived injustice of the process can itself impede return to work [Sullivan et al., 2008; Franche et al., 2009].

Some of the scientific literature that has been relied on to show that early return to work reduces work disability is based on randomized control trials that measure return to work by the cessation of workers' compensation benefits, a measure said to be more "objective"[Lippel, 2010b]. In some studies, conclusions are drawn regarding return to work even though there is no information on whether the worker is actually working, only on whether benefits have ceased [Dasinger et al., 2001]. Some studies using such measures conclude that early return to work is not only effective in reducing disability but also that it is cost effective, which may then lead to a change in legislation or policy, mandating return to work before the injury is healed. In an extreme example, the Canadian province of Nova Scotia adopted a regulation limiting benefits payable to workers diagnosed with fibromyalgia or chronic pain, rationalized by a "tough love" approach designed to make workers more active. The regulation was struck down by the Supreme Court of Canada as being discriminatory against a category of people with disabilities [Nova Scotia, 2003]. Other Canadian provinces are more subtle, but their programs promoting early return to work are known to have had adverse effects on some workers [MacEachen et al., 2007b] and have proven frustrating for service providers [MacEachen et al., 2011]. Workers' compensation programs in Australia and North America have implemented aggressive early return to work programs that have indeed reduced the numbers of workers receiving benefits. The OECD has been a key player in promoting these types of interventions, which are now spreading to European jurisdictions [Organisation for Economic Co-operation and Development, 2007, 2009, 2010].

Support for return to work that is provided for under workers' compensation systems is often linked to the costs that would be incurred by the system if the worker were not to be rehabilitated. Yet the nature of compensation available often fails to meet the needs of those who are injured, a situation that is particularly acute for the precariously employed [Azaroff et al., 2004; Quinlan, 2004], who are both more likely to be assigned dangerous work [Johnstone et al., 2001; Quinlan et al., 2001; Smith et al., 2010], and more likely to receive a level of benefits that does not reflect the impact of the injury on their working and earning capacity [Cox and Lippel, 2008; Smith et al., 2010]. This, in turn, will influence the support these workers will receive when they are permanently disabled because of work injury, underestimation of the value of their earning capacity will then lead to an underestimation of rehabilitation requirements.

\section{DESIGNING A WORKERS' COMPENSATION SYSTEM TO ENSURE FAIR COMPENSATION}

In designing a worker-centric workers' compensation system, it is not only the broad conception but also the 
technical details that make the difference in the experience of the claimant. After discussion of two current models of compensation, the New Zealand Accident Compensation scheme, and disability insurance in the Netherlands, an amalgam of the various aspects of Canadian legislation will be presented.

\section{Accident Compensation in New Zealand}

\section{Overview of the New Zealand scheme}

New Zealand replaced workers' compensation legislation and tort based recourse by a no-fault accident compensation scheme, for all types of accidents, in legislation that has been in force since 1974 [Ison, 1980], but which has undergone a series of reforms over the years.

Founding principles The system is founded on principles developed by Sir Owen Woodhouse [New Zealand Royal Commission of Inquiry into Compensation for Personal Injury, 1967], and to this day these principles, at least in theory, remain as underpinnings of the system. A recent evaluation [PricewaterhouseCoopers, 2008], examined how the scheme measures up to these principles, which were included in the report in their original wording:

(1) Community responsibility: In the national interest, and as a matter of national obligation, the community must protect all citizens (including the selfemployed) and the housewives who sustain them from the burden of sudden individual losses when their ability to contribute to the general welfare by their work has been interrupted by physical incapacity.

(2) Comprehensive entitlement: All injured persons should receive compensation from any community financed scheme on the same uniform method of assessment, regardless of the causes which gave rise to their injuries.

(3) Complete rehabilitation: The scheme must be deliberately organized to urge forward the physical and vocational recovery of these citizens, while at the same time providing a real measure of money compensation for their losses.

(4) Real compensation: Real compensation demands for the whole period of incapacity the provision of income-related benefits for lost income and recognition of the plain fact that any permanent bodily impairment is a loss in itself regardless of its effect on earning capacity.

(5) Administrative efficiency: The achievement of the system will be eroded to the extent that its benefits are delayed, or are inconsistently assessed, or the system itself is administered by methods that are economically wasteful.

Coverage The scheme provides coverage for all injury caused by accident (including injuries sustained in the context of medical treatment), and for occupational disease as defined in the Act, with the exception of mental health problems, which are not covered under the current scheme unless caused by physical injury or certain criminal acts [ACC coverage]. Everyone who has an accident in New Zealand has coverage. The system also provides benefits in the event of accidental death.

Benefits The economic benefits initially provided were based on a classic temporary/permanent (partial or total) disability model, providing for $80 \%$ of lost income during temporary disability and a pension for permanent disability that varied depending on the level of impairment. If no work-related income (income earned in New Zealand) is lost, no benefit is paid for wage loss.

Although the level of benefits for temporary disability has remained the same (80\%), the permanent disability provisions no longer provide for a pension for those who suffer partial permanent impairment, and only those who remain totally disabled (narrowly defined in practice) will continue to receive a weekly pension. A lump sum for permanent disability over $10 \%$ is also provided.

Healthcare benefits and physical and social rehabilitation support is provided. Vocational rehabilitation and educational support for injured children are also available.

Financing Initially there were three funds that financed the New Zealand scheme: an earner fund, for all injuries suffered by those who work (with the exception of automobile injury) was completely financed by employers; an automobile fund was financed by licensing of drivers and cars; and the balance (accidents to non-earners), was financed by taxes. One of many major reforms, introduced by the National government in the early 1990s, and that survives today, revamped the financing scheme so that there are now many more funds, and employers only fund the costs of work injuries to salaried workers, while the self-employed finance injuries to the self-employed. Other funds covering non-work injuries and treatment injury are paid for by levies to earners and the self-employed, the motor vehicle account is financed by levies collected in the licensing process and a petrol excise duty, and injuries to non-earners are funded by Government [Accident Compensation Commission, 2010]. Experience rating of business premiums was introduced in 2011 [ACC experience rating].

Exclusive remedy provisions In exchange for access to a no-fault system, those injured by accident in New 
Zealand are unable to sue responsible parties for damages, including for malpractice suits [Davis et al., 2002]. This includes all potential claimants, be they adults, children, New Zealand residents and, in some cases, tourists [Callander and Page, 2003].

\section{Does the New Zealand scheme provide adequate benefits and appropriate support for return to work while reducing adversarial relations, stigma and co-option of science?}

The Accident Compensation scheme in New Zealand is the subject of a broad consensus in the population, and spokespersons for business and for unions are strongly supportive. There is debate as to certain aspects of the scheme (will it continue to be publicly managed, as now, or will it be privatized in whole or in part, should they have introduced experience rating or not), but there is strong support for the universal no-fault scheme. There are many advantages in this system, as compared to workers' compensation programs in Canada and the U.S., but also some weaknesses. An overall comment is that this unified scheme is very vulnerable to shifts in political masters. When a conservative government (National Party) came to power, benefits were slashed and the core of the scheme was gutted by a reform enacted in 1992 [Miller, 1993; Campbell, 1996]. When Labour returned to power many, but not all, of the important cutbacks enacted by the conservatives were the subjects of reform, in legislation enacted in 2001.

The inclusion of all forms of accidents avoids litigation with regard to causation of injury in cases where the claimant is exposed to a variety of confounding causes for the injury, some of which relate to non-work accidents. It also avoids debate as to the definition of "work accident" at the entitlement stage, and thus cases that would be litigious in a North American workers' compensation scheme, such as commuting accidents and accidents during breaks, are automatically covered. Nonetheless, because disease is excluded from the purview of the Act, much medico-legal debate has simply been transferred from the issue of work/non-work, to the issue of traumatic/non-traumatic causation of the disability. When disease is work related, it will be covered, but the definition of occupational disease is narrow and claims are often denied [Dew, 2002; Jaye and Fitzgerald, 2010]. As Dew suggests, co-option of science may well persist in a no-fault system, particularly when causation is a key issue, as it is with occupational disease claims in New Zealand. In the nonwork context, determining whether injury is caused by trauma (covered) as opposed to gradual onset (not covered) is essential, and provides an opportunity for contestation and litigation. Exclusion of coverage for most mental health problems, including those caused by a traumatically stressful event other than a crime, is particularly problematic.

Compensation for "medical injury" is available but difficult to access [Davis et al., 2002]. Restructuring of the financing mechanisms that now require determination as to whether or not an injury is work related has eliminated a key advantage to the New Zealand scheme, and provided an incentive for employers to ensure that a given claim not be considered a work injury, a tendency most likely exacerbated by the introduction of experience rating in 2011.

Benefits are geared to pre-injury earnings, which is key to the success of such a scheme. However, the system works less well for the precariously employed or those who are not working at the time of the accident. Some no-fault motor vehicle accident compensation schemes, for example that in force in Québec, deem a minimum earning ability for the unemployed or homemakers, but the New Zealand scheme provides, with few exceptions, no wage-based compensation to those not working at the time of the accident. Given that pre-injury earnings also drive vocational rehabilitation, this problem is exacerbated, and disproportionately affects women, and those who are more likely to be unemployed, (Maori, Pacific Islanders). The absence of compensation for partial permanent disability, other than the lump sum payment, is also problematic.

According to several sources interviewed, the ACC provides seemingly outstanding, high quality health care and physical and social rehabilitation services to all who are disabled by accident and pays family members in some cases to care for disabled claimants, a clear advantage to victims of catastrophic injury caused by a nonwork related accident.

Although some vocational rehabilitation is also provided, it has been the subject of criticism in recent years [Armstrong and Laurs, 2007]. This study found that many of those who suffer accidental injury end up on means tested benefits after having been deemed capable of full time employment by the ACC, even though, in practice, no employment is available.

The New Zealand example shows that a universal accident compensation scheme can reduce in part, but not completely, the adversarial nature of the system. Stigma is also a key issue to be addressed by an ideal system, and practices that contribute to the stigmatization of claimants also exist in New Zealand. Use of video surveillance for claims management has, at times, been encouraged by the ACC itself, and an ACC spokesperson interviewed suggested that showing clandestinely filmed videotapes of claimants on television was an effective deterrence of abuse. 


\section{Compensation for Disability in the Netherlands}

\section{Overview of Disability insurance in the Netherlands}

Since 1967, disability insurance has been provided in the Netherlands regardless of the cause of disability [Pennings, 2002; Wilthagen, 2002]. Unlike the New Zealand scheme, the right to sue is not affected by the scheme, yet few law suits are filed, given the high level of support provided to those with disabilities. Like the New Zealand scheme, the Dutch Disability Insurance framework has undergone numerous changes over the years, and is vulnerable to political pressure to reduce the number of people receiving disability benefits [van Oorschot and Boos, 2000]. Recent OECD reports on disability management illustrate the type of pressure placed on the system to reduce the numbers of beneficiaries [Organisation for Economic Co-operation and Development, 2009].

Coverage Insurance is provided for those who are disabled by either injury or disease. Those insured include people who work or who are temporarily unemployed, children and, depending on the period, the self-employed. Risks covered include both the professional and non-professional (the Dutch refer to risque professional and risque social), and cause of disability is irrelevant. The public social insurance applies after the first two years of sickness absence (paid by the employer). Psychiatric disability is covered, and has represented a significant proportion of claims in recent years [Wilthagen, 2002].

Benefits Strong incentives to encourage employers to "manage disability" of their workers have been introduced by the revamping of the scheme, so that, since 2002, for the first 2 years of sickness absence, the wage replacement (between $70 \%$ and $100 \%$ of salary, depending on collective agreement top-up provisions) must be provided by the employer. After the first 2 years, the public scheme applies, a scheme now heavily emphasizing return to work (it is called the Work Capacity Act since 2006). After 90-95 weeks of sickness absence, the social insurance physician assesses the worker and entitlement is determined on the basis of that physician's evaluation of both the efforts (employer and worker) made to return to work and the impact of disability on work capacity. The latter is measured by the impact on earnings, so that those who had low earnings at the time of injury are disadvantaged. If loss of wages is deemed to be less than $35 \%$, the employee is not judged to be work disabled. A partially disabled employee (between $35 \%$ and $80 \%$ ) is eligible for benefits, and may earn some income from work while keeping benefits. If the employee has a loss of earning capacity of $80 \%$ or more of wages, but not a permanent loss, the employee will receive $70 \%$ of last earned wages. If the same level of wage loss is long-term, benefits are set at $75 \%$ of last earned wages.

Healthcare and rehabilitation benefits are provided to the disabled, sometimes through special programs, sometimes through more general provisions.

Financing and administration Employers are responsible for providing sickness benefits for the first 2 years and many have private insurers who participate in the claims management process. Liability of employers for the first 2 years is seen as a form of experience rating, and has resulted in changes in return to work practices but also in hiring practices [van Oorschot and Abrahamson, 2003]. Occupational physicians play a key role in the Dutch scheme, and every employer must provide access to an occupational physician under the legislation. These physicians play an active role in "disability management" and yet the controls on workers by these physicians appear to be less constraining than those associated with disability management in North America. An important six-country study on work disability that included the Netherlands, showed that the less constraining system in that country, which, for instance, did not require medical corroboration of illness in the first weeks, was more conducive to successful return to work [Anema et al., 2009]. There are also specific roles reserved for the Social Security physicians [Kok et al., 2008].

\section{Does the Dutch scheme provide adequate benefits and appropriate support for return to work while reducing adversarial relations, stigma and co-option of science?}

By providing a good level of wage-based benefits to those active in the workforce for all disability regardless of cause the system in the Netherlands has been one of the most interesting models available. Scandinavian countries, like Sweden and Denmark, have similar systems, although it is important to note that all these systems are constantly changing, and are notably affected by increasing emphasis on return to work incentives [van Oorschot and Abrahamson, 2003; Organisation for Economic Co-operation and Development, 2009; Stahl, 2010]. Key informants consistently report that practices such as private policing of claimants by detectives are unheard of and there is also a consistent discourse of respect for the claimants by system administrators interviewed in the Netherlands. This said, changes in recent years that leave in the hands of private employers and their insurance companies the management of sickness absence during the first 2 years may well affect the social dynamics governing 
sickness and disability management. On the one hand, trade unions and collective agreements have been found to play a more important role in providing higher levels of salary replacement to the sick and disabled, as public systems have undergone cutbacks [Yerkes and Tijdens, 2010]. On the other hand, in order to reduce dependency on disability insurance, attempts have been made to gain control of physician gatekeepers by providing them with guidelines in disability assessments [Meershoek et al., 2007] and by promoting "evidence based" insurance medicine [Kok et al., 2008].

As documented by van Oorshcot and Abrahamson, some have criticized the system for being costly, and explain that employers avoided directly hiring employees to avoid liability for sickness absence [van Oorschot and Abrahamson, 2003], preferring to hire under temporary employment contracts, and using the system to gently dispose of less productive workers, rather than adding them to the list of unemployed [van Oorschot and Boos, 2000]. The disability insurance system itself was labeled as the cause of "the Dutch disease" [Aarts et al., 1996], and this stigmatizing discourse has been praised by some as an effective measure in justifying the cutbacks implemented in the 1990s and the more stringent management of the system in recent years [Blumkin et al., 2008]. New incentives to promote return to work of the partially disabled have led to a significant overhaul of long-term protections and benefits under the current system will be reduced if efforts to return to work are deemed to be insufficient [Organisation for Economic Co-operation and Development, 2008].

Like all systems discussed here, the Dutch system is continually changing, and assessment of the impact of changes on claimants managed under the more stringent criteria introduced in the last decade is required.

\section{Workers' Compensation in Canada: Selecting the Best Aspects of Each Provincial System}

All compensation systems, be they U.S. style workers' compensation systems or New Zealand style no-fault systems for accident compensation regardless of cause, will be structured around similar basic frameworks [Ison, 1998]. The parameters of the different items within those frameworks often provide the key distinctions between an equitable and an inequitable system. New Zealand and the Netherlands provide coverage to a broader range of people with disabilities, although for many North American jurisdictions, the current socio-political context makes such reforms unlikely in the short term. However, reform of classic workers' compensation systems may be a more easily attainable goal, if the objective is to ensure workers' compensation better respects workers' dignity. To this end, key elements of workers' compensation systems that are more favorable to workers should be kept in mind. In Canada, although no one system is ideal, provincial compensation systems each have some advantageous characteristics.

In a study on labor standards in North America Block and Roberts found that, in general, workers' compensation systems in Canada provided better protection than those in the United States, while U.S. occupational health and safety legislation provided better protection than some Canadian legislation [Block and Roberts, 2000]. As previously mentioned, all Canadian workers' compensation systems replace the tort system and workers and their dependents cannot file tort claims against their own employers and lawsuits against any other employer covered by the scheme are sharply curtailed. The system is a "no fault" system, replacing civil liability by access to benefits regardless of the circumstances of the injury, the justification for the regime's financing by employers who are protected, in exchange from lawsuits.

Workers' compensation is of provincial jurisdiction in Canada where thirteen distinct systems are currently in force. Table III provides an amalgam of protections that currently exist in at least one Canadian jurisdiction, although no single compensation system provides all these protections.

Some of these attributes exist in almost all Canadian provinces and Territories, while others only exist in one or two jurisdictions. For example, all jurisdictions cover injuries attributable to events occurring out of and in the course of employment, and occupational diseases, both scheduled and unscheduled, but only some provinces cover mental health problems attributable to chronic stress [Lippel and Sikka, 2010] and only some provinces have irrefutable presumptions of causation [Lippel, 2010a]. Almost all provinces provide benefits set at $85 \%$ of net earnings or higher, but only Québec guarantees a minimum level of benefits, and only in Manitoba is there no set maximum with regard to insurable earnings. Most provinces have some provisions on rehabilitation and return to work, but there is a huge disparity between provinces as to details. All provinces provide health care required by compensable injuries, but only in Québec is the Board bound by the opinion of the treating physician with regard to certain issues. All provinces have a public, not-for profit workers' compensation board and most have some form of ombudsman and some form of independent appeal tribunal. All provinces but Québec have some form of free worker representation, while Québec is one of few jurisdictions where the appeal tribunal is not bound by workers' compensation board policy. Details as to nuances applicable to each of these issues are continually changing and beyond the scope of this article, but available from the Association of Workers' Compensation Board of Canada [AWCBC, 2011]. While the list is far from 
TABLE III. Broadest Protection Currently Available in a Workers' Compensation System in Canada

\author{
Coverage \\ Industries covered \\ Workers covered \\ Entitlement \\ Sources of disability \\ Evidentiary requirements \\ Compensable consequences \\ Benefits \\ Minimumlevel \\ Maximum insurable earnings \\ Level of benefits \\ Rehabilitation \\ Physical, social, and occupational rehabilitation \\ Early return to work
}

Access to support

Health care

Access and coverage

Administration

Adjudication

Appeal

Representation

External oversightmechanisms

Financing

Whopays

Experience rating
All industries including small workplaces, agriculture and home-based work
All workers including dependent contractors, casual, domestic, and agricultural workers

All types of injuries for which work was a contributing factor; all diseases, including mental illness, for which work was a contributing factor, regardless of whether they are listed

Legislative presumptions regarding workinjury and occupational disease. Some diseases are irrefutably presumed to be work related (asbestosis and mesothelioma)

Physical and mental consequences of work accidents and diseases including chronic pain

Regardless of pre-injury earnings benefits calculated on the basis of minimum wage for a 40 -hr week No maximum

$90 \%$ of net or $75 \%$ of gross pre-injury earnings

Objectives should include maximizing return to pre-injury abilities even if return to work is not an objective Assignment of light work should be contingent on approval of treating physician. Light work must be meaningful and favorable to rehabilitation. A minimum of pre-injury salary should be paid, regardless of the tasks

Occupational rehabilitation support should not be dependent on pre-injury earnings (currently no model complies)

All health care required by a compensable condition should be covered. Healthcare provider of the worker's choice. Access to specialized occupational disease clinics available without cost

Public, non-profit compensation board

Independent (not bound by compensation board policy) appeal tribunal accessible without cost

Worker advisor available without cost

Ombudsman or Fair Practice Commission

Employercontributions exclusively

Experience rating minimized to avoid perverse effects (i.e., incentives to contest claims or provide inappropriate temporary work assignments)

Injured workers' jobs protected for up to 2 years after beginning of absence for workinjury exhaustive, the items identified in Table III can serve as benchmarks to which other systems can be compared.

\section{CONCLUSION}

In this article we have provided an overview of key principles of classic workers' compensation systems that compensate for disability attributable to work accidents and occupational diseases. Specific challenges for compensation systems have also been discussed, including medico-legal issues, the potential perversion of science and medicine, and the danger of stigmatization of claimants. In critiquing the classic compensation systems it is important to include considerations of increasingly precarious employment [Quinlan, 2004; Underhill, 2008; Smith et al., 2010] and the health consequences of work intensification [European Agency for Safety and Health at Work,
2007], notably mental health problems and musculo-skeletal disorders. Two other models providing economic support for those with disabilities were examined: accident compensation in New Zealand and sickness/disability insurance in the Netherlands.

A human rights approach, focused on worker dignity, was chosen as a framework for this article, and making the "business case" for such an approach is both beyond the scope of the article and, many would think, inappropriate, given the primacy of human rights over economic considerations [Sen, 2000]. This said, there is a wealth of literature showing the importance of fairness in the prevention of long-term disability in the employment context [Sullivan et al., 2008; Hepburn et al., 2010], so it should not be presumed that a human rights approach is antithetical to an approach based on economic considerations. 
International Labor Organization (ILO) conventions adopted in the early 20th century (ILO Convention C017) have had an influence in the development of social security/workers' compensation legislation throughout the world, as have ILO conventions on Medical care and sickness benefits (ILO Convention C130). At times, provisions of these conventions have protected national schemes from cutbacks that could have brought some of the more comprehensive disability insurance schemes under the threshold of minimum benefits guaranteed by the conventions, notably in New Zealand [Campbell, 1996] and the Netherlands [Pennings, 2002].

Social security systems throughout the world provide some form of support for injured workers, support that is not financed by workers' contributions, at least for the costs attributable to employment injury. Often the social security system goes beyond coverage for work injury, to include coverage for non-work related injury and illness, and in those cases benefits may be financed by contributions from both workers and employers. Many systems are grappling with the challenges of changing work patterns for social security systems, seeking ways to insure coverage for the self-employed and those working in precarious employment relationships [Pieters, 2000]. Each country's system is complex and most aspire to meet the requirements defined in the ILO conventions, even in those countries that have not ratified those conventions.

Although this article identifies key issues to promote the dignity and equality rights of injured workers in the context of a compensation system, any reform must necessarily be designed in a way that takes into account the specific social, political, and legal context of the system.

Importing models from outside to a country that does not have the same type of social legislation, including access to universal health care, for example, will certainly require the development of a model adapted to that context. An international overview, albeit partial, can nonetheless provide ideas as to components to be included, or avoided, in a good and fair system. Regardless of the choices to be made, any reform of workers' compensation should guarantee that the level of benefits be based on a percentage of pre-injury earnings, ideally with a baseline below which benefits should not go. Other suggestions may be found throughout this article. Regardless of the structure of the scheme, the philosophy of the institution responsible for its implementation must, itself, be predicated on respect for claimant dignity, fairness and justice, and on the avoidance of stigmatization, if a system is going to better serve those who are injured.

\section{ACKNOWLEDGMENTS}

The author wishes to acknowledge the support of the Social Science and Humanities Research Council of
Canada whose financing of several research projects and the Canada Research Chair in Occupational Health and Safety Law contributed to the gathering of the material discussed. Ideas of the author have also been enriched by exchanges with participants in the Work Disability Prevention Program at the Dalla Lana school of public health at the University of Toronto (Canadian Institutes of Health Research (CIHR) grant(s) FRN: 53909).

\section{REFERENCES}

Aarts L, Burkhauser RV, de Jong PR. 1996. Curing the Dutch disease. An international perspective on disability policy reform. Avebury, U.K.: Aldershot.

Accident Compensation Commission. 2010. Annual report 2010 Wellington: Accident Compensation Commission.

Anema J, Schellart A, Cassidy J, Loisel P, Veerman T, Van der Beek A. 2009. Can cross country differences in return-to-work after chronic occupational back pain be explained? An exploratory analysis on disability policies in a six country cohort study. J Occup Rehabil 19:419-426.

Armstrong H, Laurs R. 2007. Vocational independence: Outcomes for ACC claimants: A follow up study of 160 claimants who have been deemed vocationally independent by ACC and case law analysis of the vocational independence process. Wellington, New Zealand: Department of Labour. p 90.

Astroff RE. 1998. Sick and tired of being sick and tired: Multiple chemical sensitivity and the law. J Environ Law Pract 8:47-62.

Aubé I. 2008. Analyse du traitement des plaintes pour harcèlement psychologique par le processus de médiation de la Commission des normes du travail (C.N.T.) et du traitement des réclamations pour lésions professionnelles attribuables au harcèlement psychologique par le processus de conciliation de la Commission des lésions professionnelles (C.L.P.): Université du Québec à Montréal.

Aubé I. 2009. Modes alternatifs de règlement des litiges relatifs au harcèlement psychologique. Regards sur le travail Québec: Ministère du Travail. p 13-18.

Azaroff LS, Levenstein C, Wegman DH. 2002. Occupational injury and illness surveillance: Conceptual filters explain underreporting. Am J Public Health 92:1421-1429.

Azaroff LS, Lax MB, Levenstein C, Wegman DH. 2004. Wounding the messenger: The new economy makes occupational health indicators too good to be true. Int J Health Serv 34:271-303.

Beardwood BA, Kirsh B, Clark NJ. 2005. Victims twice over: Perceptions and experiences of injured workers. Qual Health Res 15:30-48.

Bernhard D, MacEachen E, Lippel K. 2010. Disability management experts and the impact of jurisdiction on practice: An Ontario example. Int J Soc Secur Work Compens 2:1-16.

Biddle J, Roberts K. 2003. Claiming behavior in workers' compensation. J Risk Insur 70:759-780.

Block RN, Roberts K. 2000. A comparison of labour standards in the United States and Canada. Ind Relat 55:273-307.

Blumkin T, Margalioth YY, Sadka E. 2008. The role of stigma in the design of welfare programs. SSRN eLibrary: http://ssrn.com/ paper $=1137843$ consulted December 30, 2011.

Boden LI, Biddle EA, Spieler EA. 2001. Social and economic impacts of workplace illness and injury: Current and future directions for research. Am J Ind Med 40:398-402. 
Bohme SR, Egilman D. 2008. Beyond reputation: Debate on the role of corporate influence in occupational and environmental medicine. New Solut 18:317-324.

Callander M, Page SJ. 2003. Managing risk in adventure tourism operations in New Zealand: A review of the legal case history and potential for litigation. Tourism Manage 24:13-23.

Campbell I. 1996. Compensation for personal injury in New Zealand. Auckland: Auckland University Press. 286 p.

Campolieti M. 2002. Moral hazard and disability insurance: On the incidence of hard-to-diagnose medical conditions in the Canada/ Quebec Pension Plan Disability Program. Can Public Policy XXVIII:419-441.

Centers for Disease Control and Prevention (CDC). 2010. Morbidity and Mortality Weekly Report 59: 897-929 at p. 899.

Chung J, Cole DC, Clarke J. 2000. Women, work and injury. In: Sullivan T, editor. Injury and the new world of work. VancouverToronto: UBC Press. p 69-90.

Coole C, Drummond A, Watson P, Radford K. 2010. What concerns workers with low back pain? Findings of a qualitative study of patients referred for rehabilitation. J Occup Rehabil 20:472-480.

Cox R, Lippel K. 2008. Falling through the legal cracks: The pitfalls of using workers' compensation data as indicators of work-related injuries and illnesses. Policy Pract Health Saf 6:9-30.

Cranor CF. 2006. Toxic torts: Science, law, and the possibility of justice. New York: Cambridge University Press. 398 p.

Dasinger LK, Krause N, Thompson PJ, Brand RJ, Rudolph L. 2001. Doctor proactive communication, return-to-work recommendation, and duration of disability after a workers' compensation low back injury. J Occup Environ Med 43:515-525.

Davis P, Lay-Yee R, Fitzjohn J, Hider P, Briant R, Schug S. 2002. Compensation for medical injury in New Zealand: Does "no fault" increase the level of claims making and reduce social and clinical selectivity? J Health Polit Policy Law 27:833-854.

Dembe A, Boden L. 2000. Moral hazard: A question of morality? New Solut 10:257-279.

Dew K. 2002. Accident insurance, sickness and science: New Zealand's no-fault system. Int J Health Serv 32:163-178.

Eakin JM. 2005. The discourse of abuse in return to work: A hidden epidemic of suffering. In: Peterson CL, Mayhew C, editors. Occupational health and safety: International Influences and the "New" epidemics Amityville. New York: Baywood Publishing co., Inc. p 159-174.

Eakin JM. 2010. Towards a 'standpoint' perspective: health and safety in small workplaces from the perspective of the workers Policy Pract Health Saf 8:113-127.

Eakin JM, MacEachen E. 2003. Playing it smart' with return to work: Small workplace experience under Ontario's policy of selfreliance and early return. Policy Pract Health Saf 1:19-42.

Eakin JM, MacEachen E, Mansfield E, Clarke J. 2009. The logic of practice: An ethnographic study of front-line service work with small businesses in Ontario's Workplace Safety and Insurance Board: Institute for Work \& Health. p 38.

European Agency for Safety and Health at Work. 2007. Expert forecast on emerging psychosocial risks related to occupational safety and health. European Risk Observatory Report Belgium: European Agency for Safety and Health at Work. p 126.

Fabris S. 2004. Fibromyalgie: l'Accès aux indemnités prévues dans la Loi sur les accidents du travail et les maladies professionnelles dans un contexte d'incertitude scientifique et médicale.
Développements récents en droit de la santé et de la sécurité du travail (2004): 275-306.

Fair Practices Commission of Ontario. 2009. Annual Report Toronto: Fair Practices Commission.

Fishback PV, Kantor SE. 2000. A Prelude to the Welfare State: The Origins of Workers' Compensation Chicago. London: The University of Chicago Press. 316 p.

Franche R-L, Severin C, Lee H, Hogg-Johnson S, Hepburn C, Vidmar M, MacEachen E. 2009. Perceived justice of compensation process for return-to-work: Development and validation of a scale. Psychol Inj Law 2:225-237.

Grant G, Studdert D. 2009. Poisoned Chalice? a critical analysis of the evidence linking personal injury compensation processes with adverse health outcomes. Melbourne Univ Law Rev 33:1-25.

Gravel S, Vissandjee B, Lippel K, Brodeur J-M, Patry L, Champagne F. 2010. Ethics and the compensation of immigrant workers for work-related injuries and illnesses. J Immigrant Minor Health 12:707-714.

Guidotti TL. 2008. Occupational medicine and the construction of “difficult reputations". New Solut 18:285-298.

Guthrie R. 2002a. Negociation, power in conciliation, and review of compensation claims. Law Policy 24:229-268.

Guthrie R. 2002b. The dismissal of workers covered by return to work provisions under workers compensation laws. Eur J Indus Relat 44:545-561.

Guthrie R, Quinlan M. 2005. The occupational safety and health rights and workers' compensation entitlements of illegal immigrants: An emerging challenge. Policy Pract Health Saf 3:69-89.

Hamm RM, Reiss DM, Paul RK, Bursztajn HJ. 2007. Knocking at the wrong door: Insured workers' inadequate psychiatric care and workers' compensation claims. Int J Law Psychiatry 30:416-426.

Hepburn CG, Kelloway EK, Franche R-L. 2010. Early employer response to workplace injury: What injured workers perceive as fair and why these perceptions matter. J Occup Health Psychol 15:409_ 420 .

Herbert R, Janeway K, Schechter C. 1999. Carpal tunnel syndrome and workers' compensation among an occupational clinic population in New York State. Am J Ind Med 35:335-342.

Himmelstein J, Buchanan JL, Dembe AE, Stevens B. 1999. Health services research in workers' compensation medical care: Policy issues and research opportunities. Health Serv Res 34:427-437.

Hurley J, Pasic D, Lavis JN, Culyer AJ, Mustard C, Gnam W. 2008. Parallel payers and preferred access: How Canada's workers' compensation boards expedite care for injured and ill workers. Healthc Pap 8:6-14.

Ison TG. 1968. The forensic lottery a critique on tort liability as a system of personal injury compensation. London: Staples Press.

Ison TG. 1980. Accident compensation: A commentary on the New Zealand scheme. London: Croom Helm.

Ison TG. 1986. The therapeutic significance of compensation structures. Canad Bar Rev 64:605-637.

Ison TG. 1998. Workers' compensation systems. In: Stellman JM, editor. Encyclopedia of Occupational Health and Safety, 4th edition. Geneva: International Labour Office.

Ison TG. 2008. Statistical significance and the distraction of "scientific proof". Canad Bar Rev 87:119-159.

Jasanoff S. 1995. Science at the bar: Law, science and technology in America Cambridge. Massachusetts: Harvard University Press. 
Jaye C, Fitzgerald R. 2010. Embodying occupational overuse syndrome. Health XX:1-16.

Johnstone R, Mayhew C, Quinlan M. 2001. Outsourcing risk?: The regulation of OHS where contractors are employed. Comp Labor Law Policy J 22:351-393.

Kok R, Hoving JL, Verbeek JH, Schaafsma FG, Smits PBA, van Dijk FJH. 2008. Evaluation of a workshop on evidence-based medicine for social insurance physicians. Occup Med 58:83-87.

Kosny A, MacEachen E, Ferrier S, Chambers L. 2011. The role of health care providers in long term and complicated workers' compensation claims. J Occup Rehabil 21:582-590.

Lacerte M, Forcier P, Hall M. 2004. Independent medical examinations for insurance and legal reports, 2nd edition. Markham: LexisNexis Canada, Inc. iii-xii and 293 p.

LaDou J. 2006. Occupational and environmental medicine in the United States: A proposal to abolish workers' compensation and reestablish the public health model. Int J Occup Environ Health 12:154-168.

Lax M, Manetti FA. 2001. Access to medical care for individuals with workers' compensation claims. New Solut 11:325-348.

Le Page JA, Iverson GL, Collins P. 2008. The impact of judges' perceptions of credibility in fibromyalgia claims. Int J Law Psychiatry 31:30-40.

Leigh J, Macaskill P, Kuosma E, Mandryk J. 1999. Global burden of disease and injury due to occupational factors. Epidemiology 10:626-631.

Lippel K. 1981 -1982. Droit des travailleurs québécois en matière de santé, 1885-1981. Revue Juridique Thémis 16:329-382.

Lippel K. 1992. L'incertitude des probabilités en droit et en médecine. Revue de droit de l'Université de Sherbrooke. p 445-472.

Lippel K. 1999. Therapeutic and anti-therapeutic consequences of workers' compensation systems. Int J Law Psychiatry 22:521-546.

Lippel K. 2003a. Compensation for musculo-skeletal disorders in Quebec: Systemic discrimination against women workers? Int J Health Serv 33:253-281.

Lippel K. 2003b. The private policing of injured workers in Canada: Legitimate management practices or human rights violations? Policy Pract Health Saf 01:1-21.

Lippel K. 2007. Workers describe the effect of the workers' compensation process on their health: A Quebec study. Int J Law Psychiatry 30:427-443.

Lippel K. 2008. Workers' Compensation and controversial illnesses. In: Moss P, Teghtsoonian K, editors. Contesting illness: Processes and practice. Toronto: University of Toronto Press. p 47-68.

Lippel K. 2010a. Workers' compensation for asbestos related disease in five Canadian provinces. Available at SSRN: http://ssrn.com/ abstract=1663408: Canadian Partnership Against Cancer and the Occupational Health Clinics For Ontario Workers (OHCOW)

Lippel K. 2010b. Le droit comme outil de maintien en emploi: Rôle protecteur, rôle destructeur Revue Pistes, http://www.pistes.uqam.ca/ v12n1/pdf/v12n1a2.pdf

Lippel K. 2011. Law, public policy and mental health in the workplace. Healthc Pap 11:20-37.

Lippel K, Sikka A. 2010. Access to workers' compensation benefits and other legal protections for work-related mental health problems: A Canadian overview. Can J Public Health 101:S-16-S-22.

Lippel K, Messing K, Stock S, Vézina N. 1999. La preuve de la causalité et l'indemnisation des lésions attribuables au travail répétitif: Rencontre des sciences de la santé et du droit. Windsor Yearbook Access Justice 17:35-85.

MacEachen E, Clarke J, Franche R-L, Irvin E. 2006. Systematic review of the qualitative literature on return to work after injury. Scand J Work Environ Health 32:257-269.

MacEachen E, Ferrier S, Chambers L. 2007a. A deliberation on 'hurt versus harm' logic in early-return-to-work policy. Policy Pract Health Saf 5:41-62.

MacEachen E, Kosny A, Ferrier S. 2007b. Unexpected barriers in return to work: Lessons learned from injured worker peer support groups. Work 29:155-164.

MacEachen E, Kosny A, Ferrier S, Chambers L. 2010. The "toxic dose" of system problems: Why some injured workers don't return to work as expected. J Occup Rehabil 20:349-366.

MacEachen E, Kosny A, Ferrier S, Lippel K, Neilson C, Franche R-L, Pugliese D. 2011. The 'ability' paradigm in vocational rehabilitation: Challenges in an Ontario injured worker retraining program. J Occup Rehabil 20:1-13.

Marshall K. 2003. Les avantages de l'emploi/Benefits of the job. no 75-001-XIF au catalogue de Statistique. Canada: Statistique Canada. p 5-14.

McGuirk B, Bogduk N. 2007. Evidence-based care for low back pain in workers eligible for compensation. Occup Med 57:36-42.

Meershoek A, Krumeich A, Vos R. 2007. Judging without criteria? Sickness certification in Dutch disability schemes. Sociol Health Illn 29:497-514

Messing K. 2002. La place des femmes dans les priorités de recherche en santé au travail au Québec (Women's Place in Workplace Health Research Priorities in Québec). Ind Relat 57:660686.

Michaels D. 2008. Doubt is their product-How industry's assault on science threatens your health. New York: Oxford University Press. 372 p.

Miller R. 1993. An analysis and critique of the 1992 changes to New Zealand's accident compensation scheme. Md Law Rev 52:10701092.

Morse T, Punnett L, Warren N, Dillon C, Warren A. 2003. The relationship of unions to prevalence and claim filing for work-related upper-extremity musculoskeletal disorders. Am J Ind Med 44: 83-93.

Morse T, Grey M, Storey E, Kenta-Bib E. 2004. Occupational disease in Connecticut, 2001. Conn Med 68:131-138.

Mustard CA, Dickie C, Chan S. 2008. Disability income security benefits for working-age Canadians. Toronto: Institute for Work and Health.

New Zealand Royal Commission of Inquiry into Compensation for Personal Injury. 1967. Compensation for personal injury in New Zealand: Report of the Royal Commission of Inquiry. Wellington: New Zealand Royal Commission of Inquiry into Compensation for Personal Injury.

Organisation for Economic Co-operation and Development. 2003. Transforming disability into ability: Policies to promote work and income security for disabled people. Paris: OECD.

Organisation for Economic Co-operation and Development. 2007. Sickness, disability and work: Breaking the barriers. Australia, Luxembourg, Spain, and the United Kingdom. Paris: OECD.

Organisation for Economic Co-operation and Development. 2008 Sickness, disability and work: Breaking the barriers. Denmark, Finland, Ireland and the Netherlands: Paris: OECD. 
Organisation for Economic Co-operation and Development. 2009. Sickness, disability and work: Keeping on track in the economic downturn. Paris: OECD.

Organisation for Economic Co-operation and Development. 2010. Sickness, disability and work: Breaking the barriers. Canada. Opportunities for Collaboration. Paris: OECD.

Pennings F. 2002. Dutch social security law in an international context. Amsterdam: Kluwer. p 279.

Philips T. 2010a. I never wanted to be a quack!: the professional deviance of plaintiff experts in contested illness lawsuits: The case of multiple chemical sensitivites. Med Anthropol Q 24:182-198.

Phillips T. 2010. Debating the legitimacy of a contested environmental illness: A case study of multiple chemical sensitivities (MCS). Sociol Health Illn 32:1026-1040.

Pieters D, editor. 2000. Changing work patterns and social security-EISS Yearbook 1999. The Hague: Kluwer Law International.

Poitras J, Bélair F, Byrne S. 2005. A reflection on unintended consequences of workplace mediation. Confl Resolution Q 23:43.

Pransky G, Snyder T, Dembe A, Himmelstein J. 1999. Under-reporting of work-related disorders in the workplace: A case study and review of the literature. Ergonomics 42:171-182.

Premji S, Messing K, Lippel K. 2008a. Broken English, broken bones? Mechanisms linking language proficiency and occupational health in a Montreal garment factory. Int J Health Serv 38:1-19.

Premji S, Messing K, Lippel K. 2008b. Would a "one-handed" scientist lack rigor? How scientists discuss the work-relatedness of musculoskeletal disorders in formal and informal communications. Am J Ind Med 51:173-185.

PricewaterhouseCoopers. 2008. Accident compensation corporation New Zealand scheme review. New Zealand: PricewaterhouseCoopers. p 48

Quinlan M. 2004. Workers' compensation and the challenges posed by changing patterns of work: Evidence from Australia. Policy Pract Health Saf 2:43-70.

Quinlan M, Mayhew C. 1999. Precarious employment and workers' compensation. Int J Law Psychiatry 22:491-520.

Quinlan M, Mayhew C, Bohle P. 2001. The global expansion of precarious employment, work disorganization, and consequences for occupational health: placing the debate in a comparative historical context. Int J Health Serv 31:507-536.

Quinlan M, Bohle P, Lamm F. 2010. Managing occupational health and safety: A multidisciplinary approach, 3rd edition. Melbourne: Macmillan.

Reid J, Ewan C, Lowy E. 1991. Pilgrimage of pain: The illness experiences of women with repetition strain injury and the search for credibility. Soc Sci Med 32:601-612.

Roberts-Yates DC. 2003. The concerns and issues of injured workers in relation to claims/injury management and rehabilitation: The need for new operational frameworks. Disabil Rehabil 25:898-907.

Roberts-Yates C. 2006. Employers' perceptions of claims/injury management and rehabilitation in South Australia. Asia Pac J Hum Resour 44:102-122.

Réseau 'Surveiller les Cancers d'Origine Professionnelle en Seine Saint-Denis' (GISCOP93). 2005. Occupational cancer in a Paris suburb: First results of a proactive research study in Seine Saint-Denis. Int J Occup Environ Health 11:263-275.

Sager L, James C. 2005. Injured workers' perspectives of their rehabilitation process under the New South Wales Workers Compensation System. Aust Occup Ther J 52:127-135.
Sen A. 2000. The discipline of cost-benefit analysis. J Legal Stud 29:931-952.

Shannon HS, Lowe G. 2002. How many injured workers do not file claims for workers' compensation benefits. Am J Ind Med 42:467473.

Smith CK, Silverstein BA, Bonauto DK, Adams D, Fan ZJ. 2010. Temporary workers in Washington State. Am J Ind Med 53:135145 .

Soklaridis S, Ammendolia C, Cassidy JD. 2010. Looking upstream to understand low back pain and return to work: Psychosocial factors as the product of system issues. Soc Sci Med 71:1557-1566.

Spearing N, Connelly LB. 2011. Is injury compensation "bad for health"? A systematic meta-review. Injury 42:15-24.

Stahl C. 2010. In cooperation we trust: Interorganizational cooperation in return-to-work and labour market reintegration Linköping. Sweden: National Centre for Work and Rehabilitation, Linköping University.

Strunin L, Boden LI. 2000. Paths of reentry: Employment experiences of injured workers. Am J Ind Med 38:373-384.

Strunin L, Boden L. 2004. The workers' compensation system: Worker friend or foe? Am J Ind Med 45:338-345.

Sugarman SD. 1998. Quebec's comprehensive auto no-fault scheme and the failure of any of the United States to follow. Cah Droit 39:303-333.

Sullivan MJL, Adams H, Horan S, Maher D, Boland D, Gross R. 2008. The role of perceived injustice in the experience of chronic pain and disability: Scale development and validation. J Occup Rehabil 18:249-261.

Thomason T, Pozzebon S. 2002. Determinants of firm workplace health and safety and claims management practices. Ind Labor Relat Rev 55:286-307.

Underhill E. 2008. Double jeopardy: Occupational injury and rehabilitation of temporary agency workers. University of New South Wales, Sydney, Australia.

van Oorschot W, Abrahamson P. 2003. The Dutch and Danish miracles revisited: A critical discussion of activation policies in two small welfare states. Soc Policy Adm 37:288-304.

van Oorschot WJH, Boos K. 2000. The battle against numbers: Disability policies in the Netherlands. Eur J Soc Secur 2:343361.

Vézina M, Cloutier E, Stock S, Lippel K, Fortin É, Delisle A, St-Vincent M, Funès A, Duguay P, Vézina S, Prud'homme P. 2011. Québec Survey on Working and Employment Conditions and Occupational Health and Safety (EQCOTESST). Montreal: Institut de Recherche Robert Sauvé en Santé et Sécurité du Travail; Institut National de Santé Publique du Québec; Institut de la Statistique du Québec. p 49. http://www.inspq.qc.ca/english/publications/default. asp?NumPublication $=1356$

Waddell G, Aylward M, Sawney P. 2002. Comparison of sickness and disability arrangements in various countries. Back Pain, Incapacity for Work and Social Security Benefits: An international literature review and analysis. The Royal Society of Medicine Press Limited, London, UK. p 73-99.

Wilthagen T. 2002. Managing social risks with transitional labour markets. In: Schömann K, Mosley H, O'Reilly J, Schmid G, editors. Labour markets, gender and institutional change: Essays in honour of Günther Schmid Northampton. MA: Edward Elgar. p 264-289.

Yerkes M, Tijdens K. 2010. Social risk protection in collective agreements: Evidence from the Netherlands. Eur J Indus Relat 16:369-383. 


\section{Legal and Statistical References}

ACC coverage: http://www.acc.co.nz/making-a-claim/am-i-covered/ index.htm\#P12_761.

ACC experience rating: http://www.acc.co.nz/for-business/experiencerating/index.htm.

Association of Workers' Compensation Boards of Canada (AWCBC, 2011): http://www.awcbc.org/, consulted December 30, 2011.

Commission de la santé et de la sécurité du travail. 2000. Commission de la santé et de la sécurité du travail: Rapport annuel d'activité 2000: Québec.

Commission de la santé et de la sécurité du travail. 2005. Commission de la santé et de la sécurité du travail: Rapport annuel d'activité 2004: Québec.

Commission de la santé et de la sécurité du travail. 2010. Commission de la santé et de la sécurité du travail: Rapport annuel d'activité 2009: Québec.

Commission des lésions professionnelles. 2000. Rapport annuel de gestion 1999-2000: Commission des lésions professionnelles: Québec.

Commission des lésions professionnelles. 2005. Rapport annuel de gestion 2004-2005: Commission des lésions professionnelles: Québec.

Commission des lésions professionnelles. 2010. Rapport annuel de gestion 2009-2010: Commission des lésions professionnelles: Québec.

ILO Convention No. C017 on Workmen's Compensation (Accidents) and C018 on Workmen's Compensation (Occupational Diseases), both adopted in 1925, have been ratified, respectively, by 71 and 60 countries, although neither the United States nor Canada ratified these conventions. The Conventions were revised by convention C121, the Employment Injury Benefits Convention, 1964 http:// www.ilo.org/ilolex/english/newratframeE.htm.

ILO Convention C130, Medical Care and Sickness Benefits Convention, 1969, http://www.ilo.org/ilolex/english/newratframeE.htm. 15 countries, including several European and Latin American countries, have ratified this convention, although neither Canada nor the United States are among them. The Canadian sickness insurance system
(Employment Insurance) would not meet the exigencies of this convention, which requires economic support for the sick for at least 52 weeks at a minimum of $60 \%$ of the worker's salary.

Nova Scotia (Workers' Compensation Board) v. Martin; Nova Scotia (Workers' Compensation Board) v. Laseur: 2003 Supreme Court of Canada. 54.

Safework Australia 2011, Comparison of Workers' Compensation Arrangements in Australia and New Zealand (2011), http://safeworkaustralia.gov.au/AboutSafeWorkAustralia/WhatWeDo/Publications/ Pages/comparison2011.aspx

Workers' Compensation Appeal Tribunal. 2006. 2005 Annual Report, Workers' Compensation Appeal Tribunal, Richmond, British Columbia.

Workers' Compensation Appeal Tribunal. 2010. Annual Report Workers' Compensation Appeal Tribunal, Richmond, British Columbia.

Workers' Compensation Board of B.C. 2000. Statistics 2000, Workers' Compensation Board of B.C : Vancouver.

Workers' Compensation Board of B.C. 2001. 2000 Annual Report of the Appeal Division, Workers' Compensation Board of B.C: Vancouver.

Workplace Safety and Insurance Appeals Tribunal. 2001. Annual Report 2000, Workplace Safety and Insurance Appeals Tribunal: Toronto.

Workplace Safety and Insurance Appeals Tribunal. 2006. Annual Report 2005, Workplace Safety and Insurance Appeals Tribunal: Toronto.

Workplace Safety and Insurance Appeals Tribunal. 2010. WSIAT Annual Report 2009, Workplace Safety and Insurance Appeals Tribunal: Toronto.

Workplace Safety and Insurance Board. 2010. WSIB Ontario Statistical Supplement to the 2009 Annual Report, WSIB Ontario : Toronto.

Worksafe BC, WorksafeBC Statistics. 2005. http://www.worksafebc. com/publications/reports/annual_reports/pub_10_20.asp.

Worksafe BC, WorksafeBC Statistics. 2009. http://www.worksafebc com/publications/reports/annual_reports/pub_10_20.asp. 